\title{
The Value and Path Selection of the Legal Culture Transmission of the University in the New Era*
}

\author{
Shiyong Song \\ School of Literature and Law \\ Qilu University of Technology (Shandong Academy of \\ Sciences) \\ Jinan, China
}

\begin{abstract}
The nineteenth congress of the communist party of China puts forward "intensify the dissemination, the construction of the socialist rule of law culture" as the moral and cultural construction of rule of law as the core target of ideological and moral construction put forward the strategic guidance. This paper mainly analyzes the main problems of education of ideological and political science in colleges and universities, and expounds the countermeasures to perfect the ideological and political education in colleges and universities.
\end{abstract}

Keywords-colleges and universities; new era; rule-oflaw culture; value and path

\section{INTRODUCTION}

On October 18, 2017, the 19th Chinese Communist Party Congress was grandly opened in Beijing. The 19th National Congress of the Party is a conference that summarizes the past, judges the present, and plans for the future. The report states: "After long-term efforts, socialism with Chinese characteristics has entered a new era. This is a new historical position for our country's development." Under this "New Era" background, it means that the construction of ideological and political education in colleges and universities in our country should make a new leap forward. The goal of popularizing the legal culture of socialism proposed by the 19th CPC National Congress, giving priority to developing education and building a world power in education requires that we must strengthen the ideological and moral construction of colleges and universities under the unified leadership of the Communist Party of China and enhance the national beliefs and cultural capabilities of teachers and students With the help of the "New Era", we will provide a solid spiritual food for the great rejuvenation of China, the realization of the Chinese dream as soon as possible and the goal of two hundred and 100 years of hard work.

*This paper belongs to the research achievement of "Cultura Communication" in the key discipline of culture and art science in Shandong province in 2017

\author{
Meng Fu
School of Literature and Law
rsity of Technology (Shandong Academy of \\ Meng Fu
School of Literature and Law
rsity of Technology (Shandong Academy of \\ Meng Fu
School of Literature and Law
Qilu University of Technology (Shandong Academy of \\ Sciences) \\ Jinan, China
}

\section{THE IMPORTANCE OF RULE-OF-LAW CULTURE IN COLLEGES AND UNIVERSITIES}

\section{A. Strengthening the Culture and Education of the Rule of Law is Conducive to the Training of University Personnel in the "New Era"}

Strengthening the culture and education of rule of law in colleges and universities is not only conducive to improving the legal quality of college students under the New Era, but also conducive to improving the students' ideological and moral qualities in the New Era. In 2017 and the 19th National Congress of the Communist Party of China, General Secretary $\mathrm{Xi}$ Jinping proposed to strengthen ideological and moral construction in the context of "a New Era." It is necessary for the people to have faith, the country has the power, and the nation has hope. Beliefs and forces contain a strong support of the elements of morality and rule of law, and the integration of internal and external can we provide a clear future and hope for the great rejuvenation of the Chinese nation. To cultivate all-round development talents, it is necessary for colleges and universities to carry out ideological and political education focusing on moral integrity and the rule of law awareness and culture outside the cultural classes. Respecting the differences among different students, we should teach students according to their aptitude, carrying out reasonable and effective learning and activities to enhance students' Ideological and moral qualities, in order to provide China with a real and powerful talent support for its prosperity and prosperity.

\section{B. Strengthening the Culture and Education of Rule of law in Colleges and Universities is Conducive to Social Stability and Development}

The influence of the rule of law culture and education in universities is influenced by the thinking of contemporary young people. General Secretary Xi Jinping pointed out in his report to the 19th Congress that "the Chinese dream is historical, realistic and future; it is our generation and even the younger generation". The thinking of the young generation is not only a job on campus but also a job outside the campus. It is not only a major event for schools but also a major event for the entire party and the whole society. What kind of young generation, what is the future of our 
motherland, college students as an important position in China's ideological and political education, their ability to accept is higher than ordinary people, their ability to learn new things is also true. The distortions of values of undergraduates and the proliferation of negative thoughts cannot be ignored for the development of socialism with Chinese characteristics and the long-term stability of Chinese society. Therefore, under the background of "New Era" It should be the focus of ideological and political education in our country.

\section{ANALYSis OF THE PROBlems FACING THE CUltURE AND EDUCATION OF RULE OF LAW IN COLLEGES AND UNIVERSITIES}

\section{A. The Ideological and Political Course Teaching in College is out of Practice}

The ideological and political course itself is endowed with a great deal of important tasks of honesty and moral awareness education and awareness of the rule of law as well as moral and legal culture cultivation, These tasks require teachers of ideological and political education in colleges and universities to conduct a wide range of students in the questionnaire survey and the collection of typical cases, and college students facing various types of moral integrity cases and cases of law to summarize, organize and explain the classroom in order to give students the right to teach Morality, View of Law and Culture. Because of these typical cases, such as campus loan fraud, the problem of college students 'honesty, college students' depression and murder, the militarization of colleges and universities and the safeguard of human rights, etc., all need to be integrated with the reality of the university and implemented in the classroom. At present, most colleges and universities do not do a good job in this task.

\section{B. The Lack of Full Participation of Ideological and Political Education in Colleges and Universities}

The ideological and political education in colleges and universities lacks the full participation of all members. Only by relying on the political orders of Party committees and administrative departments or passively adapting to the changes and objective requirements of the exogenous environment, it is impossible to internalize the ideological and political work and education into one's own needs. Managers only manage, ideological and political theory class just to teach theoretical knowledge. 1 The problem is that there is a huge gap between the standard of management of higher education and the teaching method of the teachers in the ideological and political education and the voluntary acceptance and transformation of students. For the recent cases of undergraduate moral integrity and lack of legal awareness, how to integrate well into the classroom and gain timely feedback from students, so that the legitimate rights and interests of students can be protected at the same time,

Zhao Tianbiao, Chen Chuo, "Problems and Countermeasures in Ideological and Political Education in Colleges and Universities", "Science Forum", April 2017, page 137. the formation of a good moral integrity within the school Culture and the rule of law culture of innovation and integration, and promote the healthy development of colleges and universities, which is still a big problem.

\section{The Evaluation System of Ideological and Political Education for College Teachers is not Enough}

At present, the evaluation system of some educators in colleges and universities is too rigid and lacks flexibility, which has seriously hampered the enthusiasm of workers. The evaluation of the effectiveness of ideological and political course in colleges and universities not only evaluates students 'academic performance and teachers' teaching content, but also evaluates whether the atmosphere of honesty and rule of law in colleges and universities is well formed and developed. The outstanding performance is whether the relationship between teachers and students is clean, pure, efficient and harmonious, whether college students can consciously prevent legal risks and moral hazard. When the risks occur, university students, teachers and colleges and universities can form a benign interaction and form perfect risk prevention and control mechanism in time to safeguard the legitimate rights and interests of colleges and universities, teachers and students.

\section{Ideological and Political Education Lacks Education to Students' Subjects}

Under the influence of western ideas, some college students have problems in their ideology and morality. The deviation of college students 'ideology from the mainstream culture in our country is very much responsible for the correction of the ideological and political teachers and universities in colleges and universities. This requires teachers and teachers in colleges and ideological and political education to combine the direction and problems of the students' deviation in their management and teaching Out of the corresponding guiding strategies and measures, from law awareness training, their own rights and interests and other aspects of comprehensive cultivation to help students establish a correct outlook on life, values and world outlook, the core point is the ethics and honesty based on the formation and spread of the rule of law culture. This kind of internal and external mode of thinking of political and ideological education can be well for college students' ideological and moral development to provide adequate nutrition.

\section{COUNTERMEASURES TO PROMOTE THE LEGAL Culture EducAtion In COLLEGES AND Universities}

\section{A. From the Political Level Firmly Grasp the Leadership of the Culture of Law and Order in Colleges and Universities, Innovative Ways of Working}

The 19th National Congress of the Communist Party of China pointed out that "ideology decides the direction of cultural progress and development path." The culture of the rule of law is an indispensable part of the ideological and political work. Our country has stepped into a "New Era." The cultural education of the rule of law wants to grasp the 
initiative. It is necessary to combine the specific conditions of the students and innovate a new way of ideological and political education. In the Internet age, in the face of the ever-changing Internet technology and its ever-increasing impact, the all-round development of people is bound to be based on the technical rationality of preparing for the technology age. ${ }^{2}$ The current Internet + platform provides a broad platform and abundant resources for ideological and moral education in colleges and universities and benign cultivation of ideological and moral standards. University students and teachers should make good use of this platform to carry out relevant work under the normative organization of colleges and universities, As soon as possible in the moral integrity and rule of law culture formation and development of a breakthrough.

\section{B. Firm Cultural Confidence, and Create a Culture of Rule of Law on Campus}

The report of the 19th National Congress once again put forward "firm cultural confidence." To strengthen the law education for college students is an important part of deepening the socialist education with Chinese characteristics and the Chinese dream publicity and education. 3 First of all, colleges and universities can start from the various activities in the school organization, such as associations, student unions, studios, etc., to strengthen the management of school organization, standardize organizational behavior, and guide them to promote the socialist core values. Second, colleges and universities to strengthen the management of student dormitories, and strive to cover all people in education, in student dormitories, to strengthen the cultural construction of quarters, to create a culture of learning the spirit of law and the atmosphere of law. Culture is of a regional nature. Talents have specific emotions. Our ideological and political education in colleges and universities should integrate with local needs and talents requirements, make full use of every minute in every corner of the university and classroom, and promote moral integrity in colleges and universities As the foundation of the rule of law culture as soon as possible the formation and development.

\section{Build High-quality Specialized Ideological and Political Education Team}

The party pointed out in the 19th National Congress of the Communist Party of China that "paying attention to cultivating professional ability and professionalism" and "insisting on combining strict management with loving care, equal emphasis on motivation and restraint, improving the cadre appraisal and evaluation mechanism, and establishing an incentive mechanism and fault-tolerant and error-

2 Xie Yujin, Lv Xuefei, "On the network content of ideological and political education," "Continuing Education Research", 2017 No.5,page 89 .

Chen Yongfu, Chen Shao-ping, Chen Guixiang, "An Investigation and Study of the Present Situation of Chinese Excellent Traditional Culture and Education in Universities - A Case Study of 10 Universities in Fuzhou University City", "Ideological and Educational Research", 2016 No.1, , page120. correcting mechanism." Ideological and political educators should strengthen learning, strengthen the construction of ethics and morality, pay attention to learning new knowledge needed in the context of "New Era", and become a "complex" talent that not only understands ideological and political work, but also understands students' psychology. It is a continuous test for colleges and universities to act as manager themselves. Only when we insist on consciously and voluntarily, strengthen the reasonableness of managers' effective evaluation of the combination, in order to ensure the smooth construction of law and order cultural system and improve development.

\section{Adhere to the Leadership of the Party Central Committee, Advance with the Times}

General Secretary Xi Jinping pointed out in the 19th NPC report that upholding the leadership of the Party Central Committee and upholding the Party's leadership over all work and the military and civilian studies of the party, government and the party are the only ones leading the party in everything. In the face of ideological and political education work, we must closely follow the mainstream thinking and grasp the great arteries of the times. This also requires that ideological and political educators in colleges and universities should grasp the students' ideological trends. According to the existing characteristics reflected by modern college students, we should adjust the work center of gravity and work methods. Based on past work experience and judgments on the specific circumstances at the current stage, we can forecast possible situations, formulate work plans and conduct ex-ante education so as to enhance the relevance and effectiveness of ideological and political education.

The rule of law, culture and politics are inseparable and are inseparable from the party's strong leadership. On the one hand, ideological and political construction and moral construction of our colleges and universities need to provide the foundation and nutrition for the construction of the culture of rule of law in colleges and universities; on the other hand, we must insist on the unified leadership of the party so as to ensure the direction of the construction of law and order culture and the guidance of ethical and honest culture in colleges and universities.

\section{CONCLUSION}

To sum up, in the context of "New Era", the ideological and political education in colleges and universities presents new problems, and at the same time, it sets new standards and new requirements for the working methods of college ideological and political educators, In college education, ideological and political education is an indispensable part and holds a pivotal position. General Secretary Xi Jinping put forward at the ideological and political work conference of the national higher education institutions: "Our colleges and universities are under the leadership of the party and colleges of socialism with Chinese characteristics "."New Era" has changed all aspects of ideological and political education in colleges and universities. Ideological and political educators in colleges and universities should give full play to their subjective initiative. The specific analysis of 
specific issues should be taken to adopt reasonable and effective new methods and solve new problems appearing in the New Era so that ideological and political education embody the characteristics of a New Era, grasp its regularity, rich in its creativity, in order to enhance its effectiveness.

\section{REFERENCES}

[1] Zhao Tianbiao. Chen Chao. The Problems and Countermeasures of the Education Mechanism of Ideological and Political Science in Colleges and Universities. The Scientific Symposium[J]. 2017.4.

[2] Xie Yyujin. Lv Xuefei. On the Expansion of Internet Ideological and Political Education Content. Continue Education Research[J]. 2017.5.

[3] Chen Yongfu. Chen Shaoping. Chen Guixiang. Research on the Education Status of Chinese Excellent Traditional Culture of College Students - Taking the 10 Universities in Fu Zhou University as an Example. Ideological Education Research[J]. 2016.1. 